\title{
The Path of Grammaticalization for Coordinate Conjunctions and its Universality
}

\author{
Ma Qinghua*
}

\begin{abstract}
From the study of polysemy of coordinate conjunctions, it can be found that there are grammaticalization processes from coordination to transition and from coordination to succession. It is a general evolutionary process in connective structures to go from non-specific semantic relationship to specific semantic relationship. This was caused by the cognitive tendency of approximately substituting typical functions for atypical functions.
\end{abstract}

Key words: Conjunction, coordination, transition, succession, grammaticalization, universality

\section{Introduction}

Word grammaticalization ('grammaticalization' for short) is a focus of modern grammar research. In the typical sense, grammaticalization means the process by which grammatical meanings derive from notional words. In a broader sense, it means the change from less functional meanings to the more functional, both of which can be said to be almost the same grammatical value. These two types of research constitute the main body of grammaticalization research done in China. This paper concerns a third domain, which has received less attention from scholars; it is a project conducted on the basis of a comparison of data from classical and modern Chinese, minority languages in China, as well as foreign languages, revealing how coordinate conjunctions derive other linking functions in the process of use in an effort to reflect the significance of linguistic universality in the study of grammaticalization.

Conjunctions in many languages have the polysemy of "coordination $\diamond$ transition $\diamond$ succession". The conjunctions “而(ér)," “以(ȳ1)" in old Chinese, "and" in English, "park" in Serbo-Croatian (a language of the Slavic group, Indo-European family), and " $e$ " in Portuguese (Latin family), all signify coordination as well as succession and transition. The

\footnotetext{
* Ma Qinghua: Institute for International Students, Nanjing University, Nanjing 210093, China. E-mail: maqh86@yahoo.com.cn. 


\section{The Path of Grammaticalization for Coordinate Conjunctions and its Universality}

conjunctions $\mathrm{Pom}^{3}$ in Li language (Zhuang-Dong group of Sino-Tibetan), mà in Vietnamese (Mon-Khmer group in the Southeast Asia), et in French, und in German and да in Russian, all signify coordination as well as transition. The conjunctions serta, dan in Indonesian (Austronesian family), pak in Czech (Slavic group of Indo-European family), and и in Russian indicate coordination as well as succession. Given such apparent universality in the polysemy of these conjunctions, a question to ask is in what order do changes occur?

In theory, conjunctions have the following sources:

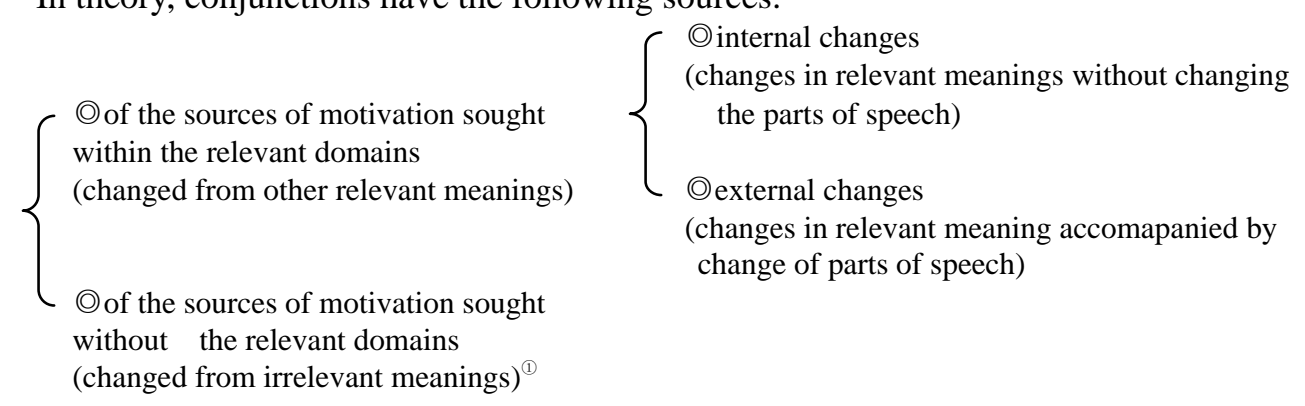

It is argued here that the path of grammaticalization proceeds in order from coordination > transition, and from coordination > succession, and not the reverse, nor any other path. The sequence of change can be summed up as coordination>succession in internal changes: a generalization that the semantic relations denoted move from a general relationship, then change to a special one with a joined structure. This process of change results from the fact that people tend to cognize the non-prototypical function with the aid of the prototypical function.

The motivation resources outside of the relevant domains sometimes are regarded as a helpful means to see clearly the sequence of internal changes. The external changes involve those in correlative sense and parts of speech, with an increase of complexity ${ }^{2}$ beyond the scope of this paper. Beyond conjunctions, the verbal markers of coordination, e.g. relative adverbs, auxiliaries, and recurrent forms of correlation (e.g. 一边(yì biān)..... 一边(yì biān) (meaning "on the one hand...and on the other"), as well as paired linking forms (e.g.“既(jì)….. 又(yòu)...(meaning "both....and...”) are not discussed either.

\section{Analyses in form}

1.1. The tendency to change from word-coordinate conjunctions to sentence conjunctions

Conjunctions are classified into two kinds: word-linking and clause-linking, depending on where the joining takes place: within a phrase or between clauses of a complex sentence (or a compound sentence). For coordinate conjunctions that have relatively broader

\footnotetext{
(1) For example, words signifying the category of littleness have changed into transitional conjunctions. See "§2. Semantic Analyses".

(2) For example, the conjunctionhood of “乃(năi)”, “又 (yòu) ” resulted from relative adverbs.
} 


\section{Ma Qinghua}

syntactic applicability, there is a tendency to change from word-linking to sentence-linking, as evidenced below.

\subsubsection{The semantic relations between words}

Polysemic relation is the epitome of the semantic relation between words, where the word-coordinate conjunctions are the oldest, the most essential of all conjunctions. Most of the languages which have conjunctions have word-coordinate ones. Chen Mengjia (1988) said too: "Most of the conjunctions in Oracle inscriptions in the Yin Ruins linked noun(s) with noun(s), whereas only a few linked two clauses." Even the most conjunction-lacking language, e.g. Tu language (a language of Altaic-Mongolian group) "only have one word-coordinate conjunction: da (and)" (Junast,1981[1]). Lhoba (Bengni-Bokr) (a language of Tibeto-Burman group, Sino-Tibetan), which has only a few conjunctions, has not only word-linking conjunctions but also fine differentiation between two kinds of conjunctions: one joining the substantivals and another for the adjectivals. The languages which borrowed conjunctions extensively from other languages have sometimes only word-coordinate conjunctions of their own, e.g. Cun (a language of Zhuang-Dong group, Sino-Tibetan family) has only one conjunction: the coordinate conjunction nam $^{l}$. Compare the counterparts in other language of Zhuang-Dong group:

\begin{tabular}{|c|c|c|}
\hline languages of Zhuang-Dong group & words & meaning \\
\hline Cun & nam $^{I}$ & \multirow{6}{*}{ and } \\
\hline Maonan(Dong-Shui branch) & ${ }^{n} \mathrm{dam}^{5}$ & \\
\hline Shui (Dong-Shui branch) & ${ }^{?}$ njam $^{5}$ & \\
\hline Yanghuang (Dong-Shui branch) & nam $^{6}$ & \\
\hline Lingao (Tai group) & hem $^{I}$ & \\
\hline Bouyei in Guiyang (Zhuang-Dai branch) & tiam $^{I}$ & \\
\hline
\end{tabular}

In addition to the word-coordinate conjunctions in Cun language, there are other common conjunctions which were borrowed obviously from Chinese, for example, $h k^{l}$ (or), $h u a n^{4} s i^{5}$ (or), $z a^{5} s i^{5}$ (or), $z i^{5} k u \partial^{5}$ (if), $t \theta \varepsilon i^{2} z e n^{4}$ (although), $d a n^{3} s i^{5}$ (but), $z i n^{2} v \varepsilon i^{3}$ (because), $s 5^{5} z i^{5}$ (therefore), and roughly so in Yanghuang and other languages (Bo Wenze 1997). Botibunia, a Russian comparative linguist in 19th century, on the basis of a large corpus, pointed out that zero conjunction appeared earlier than conjunctions themselves. Speaking of coordinate and subordinate linkage, Botibunia's contemporary (and compatriot) Kozuhi believed that the appearance of the former was earlier than the latter. In China, Hu Menghao(1980) agreed, "this statement is all correct."

\subsection{2. the contexts}

The contexts in which coordinate conjunctions can be used fall into three types:

[A]linking two coordinate substantivals;

[B]linking two coordinate predicates or subject-predicate phrases;

[C] linking two coordinate clauses (with a pause in between). 


\section{The Path of Grammaticalization for Coordinate Conjunctions and its Universality}

The observations about the contexts in which coordinate conjunctions can be syntactically applied are summed up in the following table. In theory, $\mathrm{B}$ can be subdivided into $\mathrm{B}_{1}$ (not to be used directly as a predicate) and $\mathrm{B}_{2}$ (to be used directly as a predicate); $\mathrm{C}$ into $\mathrm{C}_{1}$ (the same subjects) and $C_{2}$ (not the same subjects ). Little of the present literature available classifies B and C into subgroups, so the following table retains the coarser classification.

\begin{tabular}{|c|c|}
\hline Application context & coordinate Conjunctions \\
\hline [A] & 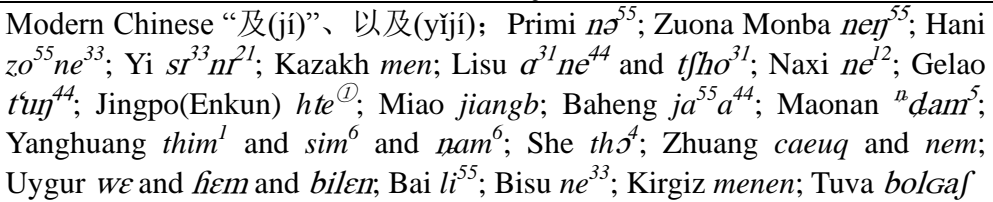 \\
\hline$[\mathrm{A} / \mathrm{B}]$ & $\begin{array}{l}\text { Wa mai; Bai } \tilde{r}^{55} ; \text { Aching } l \sigma^{255} ; \mathrm{Li} k h u^{\prime} \text { and } n u k^{7} ; \text { Lhasa (Tibetan) } \\
t^{t} a \eta^{13} ; \text { Kangjia } m a \text {; Derung } n i \eta^{55} \text { (used in }[\mathrm{B}] \text { as word-coordinate conjunction } \\
\text { under some conditions); Kirgiz dzana; Tuva bilen; Jingpo (Zaiwa) } e^{255}\end{array}$ \\
\hline [B] & Lhoba(Bengni-Boler) to \\
\hline$[\mathrm{B} / \mathrm{C}]$ & Xibe bim; Bisu $z a u^{33}$; Late-modern Chinese “而且”(érqiě) \\
\hline$[\mathrm{A} / \mathrm{B} / \mathrm{C}]$ & $\begin{array}{l}\text { English and; Kazakh jäne; Sweden och; } \\
\text { Old Chinese “而”(ér) }\end{array}$ \\
\hline
\end{tabular}

As seen from the above table, the coordinate conjunctions of type [A] are the first and dominant, $[\mathrm{A} / \mathrm{B}]$ the second. Another phenomenon worthy of note is that in most of the languages, sentence-coordinate conjunctions are either unknown or not in common use ${ }^{\circledR}$. No sentence-coordinate conjunction has so far been found which is only used in [C]. In contrast, for some languages, for example, Hani, Naxi, Yanghuang, Aching, "their juxtaposed phrases do not have to be joined by conjunctions, but it is most common to put a conjunction between them." Moreover, sentence-coordinate conjunctions ${ }^{(4)}$ which can link two clauses in C pattern, can, generally speaking, join first of all two predicates in B pattern, e.g. “而且(érqiě)" (which came into being at the latest in the Yuan Dynasty and Ming Dynasty), with a common practice to link two one-syllable adjectives (sometimes verbs) and to function as word-coordinate conjunctions (e.g. (1)-(3)) (B pattern). A few examples of the use of “而且” as clause-linking conjunction existed (e.g.(4)) (C pattern ), and its usage indicating progression did not prevail till the Qing Dynasty.

(1) Zhè făr zhēnshì miào <érqiè> líng. (这法儿真是妙而且灵。(《西游记》) / this method is really fine $<$ and> effective. (pilgrimage to the west)

(2) Wú Yì yǒu yíi mèi, měi <érqiě> xián. (吴懿有一妹, 美〈而且>贤。(《三国演义》) / wu yi has a

\footnotetext{
${ }^{3}$ For example, Primi, Aching, Li, Lhoba (Bengni-Bokr), Zuona Monba, etc. There are sometimes relative abverbs indicating sentence-juxtaposition, and to get a coordinate sentence, a few languages (e.g. Kangjia) resorted to morphology.

(4) Here it refers only to co-existent juxtaposition, with some exceptions to juxtaposition. For example, its linker is “而且(érqiě)”, “同时(tóngshí)”, is also a linker, which expressed “simultaneousness”.
} 


\section{Ma Qinghua}

younger sister, who is pretty <and> virtuous. (the romance of the three kingdoms)

(3) Wēi Ž x̌ <érqiě> yōu.(微子喜<而且〉忧。(《封神演义》) / weizi was happy 〈and> sad. (the legend of gods)

(4) Zhū jiān guànmăn, xiāngcì jiù fù; <érqiě> míngzhèng diănxíng; lì xuè shèxiăng. (诸奸贯满,相次 就缚;<而且>明正典刑,沥血设飨。(冯梦龙: 《醒世恒言》) / the evils, who had committed so many crimes, were bound fast in their turn to the jail, <and> then sentenced to death according to the law. (feng menglong: lasting words to awaken the world)

All the word-coordinate conjunctions joining two arguments (B pattern) cannot be raised to be the sentence-coordinate conjunction ( $\mathrm{C}$ pattern). In (5)a, (6)a (Modern Chinese), juxtaposed phrases can only be the lower-level members of the clause subject-predicate, not the upper-level predicate. So, (5)b-(6)b cannot be regarded as single sentences.

(5) a.Tāde yǒnggăn < hé> jiānqiáng lìng suǒyǒu rén zhéfú. (他的勇敢<和〉坚强令所有人折服。/ His bravery <and> determination make himself admired by everyone.)

b. *Tā yǒnggăn $<$ hé> jiānqiáng (*他勇敢<和>坚强。 $*$ He brave <and > firm.)

(6) a.Wǒ měi tiān dōu yào fúshì nǐ chīfàn $<$ hé> shuìjiào.(我每天都要服待你吃饭<和>睡觉。

/Everyday I was to attend your dining <and> sleeping.)

b. *Nǐ chīfàn <hé> shuìjiào .(*你吃饭<和>睡觉。/You dining <and> sleeping.)

A generalization of these three shows that the raising of the domains relevant to the coordinate conjunctions follows the order "(A) $>[(\mathrm{A}) / \mathrm{B}]>[(\mathrm{A}) / \mathrm{B} / \mathrm{C}]$ ". That is to say, if there is $A$, then " $[A]>[A / B]>[A / B / C]$ "; if without $A$, then " $[B]>[B / C]$ ".

\subsubsection{Positions}

Conjunctions are termed "middle-position words", which can be used in a balanced way between the former-item and the latter-item but classified neither into the former-item nor into the latter-item. Depending on whether the clause in which the markers appeared is the former item or the latter item in a compound sentence, the sentence-relevant markers are classified as the former-item mark and latter-item mark. It can be seen that the middle-position words playing the word-coordinate role for sentence juxtaposition often move on to the latter items. Compare (7) with (8).

(7) Zăiyú zhī cí, yă <ér> wén ye. (宰予之辞, 雅<而>文也。(《韩非》) / Zaiyu's words are elegant $<$ and > graceful. (Han Fei)(word-coordinate)

(8) Míng zhě yuăn jiàn yú wèi méng, <ér> zhì zhě bì wēi yú wú xíng. ( 明者远见于未萌, <而〉智者 避危于无形。/ The wise foresaw omens from whatever did not happen, <and> the brilliant prevented harm from all hidden danger. (Historical Records) (sentence juxtaposition)

“而”(er) in (8) is an example of conjunction having become attached to the latter item, similar to the case with English "and" . In fact, a word-coordinator tends to move on, and mostly it appears before the last element of three items in juxtaposition, e.g. in Chinese “小 张、小王和小李” (Little Zhang, Little Wang and Little Li), and likewise with Primi (Qiang 


\section{The Path of Grammaticalization for Coordinate Conjunctions and its Universality}

branch, Tibeto-Burman group, Sino-Tibetan Family), Hani (Yi branch, Tibeto-Burman group, Sino-Tibetan Family), Indonesian (Austronesian family), English (Germanic group, Indo-European family), and Portuguese (Latin group, Indo-European family). This usage shows a strong universal tendency. In some languages, however, it tends to be attached to the former item, e.g. $\mathrm{li}^{55}$ in Bai (Yi branch, Tibeto-Burman group) as a word-coordinate conjunction, is a middle-position word but when indicating clause transition it is attached to the former item. Compare:

(9) $\mathrm{yo}^{21}<\mathrm{li}^{55}>\mathrm{mo}^{31}$ (I and she)

(10) $\mathrm{ga}^{55} \mathrm{ke}^{55} \mathrm{ji}^{44} \mathrm{tshe}^{44} \mathrm{la}^{21} \mathrm{tua}^{42}<\mathrm{li}^{55}>, \mathrm{me}^{55} \mathrm{ji}^{44} \mathrm{tshe}^{44} \mathrm{ta}^{44} \mathrm{mu}^{55} \mathrm{no}^{33} \mathrm{pe}^{21} \mathrm{ua}^{55}$ (Literally, we today will not finished though, tomorrow mill a while more. / i.e. Though we shall not finish milling today, we can do it tomorrow by milling a while more)

Whether they are attached to the former item or latter item, they have all resulted from the increased semantic load of the two items giving rise to a pause in intonation and restricted understanding, therefore a break in structure. This phenomenon is generally understood to be the consequence of word-coordinators changing into sentence-conjunctions. On the contrary, sentence-conjunctions cannot be changed into middle-position words by getting degraded to be used as word-linking elements, because their structural subordination has not changed. For example, “但”(dàn, but) in Chinese, a sentence-transition word expressing contrast, is still attached to the latter item; “由于” (yóuyú, because of), a causal conjunction, while joining clauses, belongs to the causal item, and remains so while joining substantivals. Compare:

(11) bú piàoliang <dàn> gèxìng shízú de nŭrén (不漂亮/<但>个性十足的女人 / a not pretty/<but> individualistic woman)

(12) tì nàxie <yóuyú> nǐ cái dūn jiānyù de xiōngdì bàochóu (替那些<由于>你/才蹲监狱的兄弟报

仇 / revenge those who went to jail <because of > you)

As for the joining function of a conjunction, the path of its change from word-linking to sentence-linking exhibits a break in structure, its principle being that the word-linking relation was copied as a clausal relation. In a word-conjunction linking framework where clauses rather than words were filled in, the structural load of word-conjunctions swelled, thus giving rise to the appearance of sentence-conjunctions.

It follows from the above-analysis that for coordinate conjunctions with broader application in syntax there is a tendency of change: "word-conjunction > sentence-conjunction". By this logic, it is inferred that while there is frequently polysemy among "word-coordinate conjunction $\diamond$ sentence-coordinate conjunction $\diamond$ sentence-transition conjunction $\diamond$ sentence-succession conjunction," it is common that the earliest usage is as a word coordinator, and then, through internal change, it comes to be used as a sentence coordinator, and finally as a conjunction of sentence-transition or 


\section{Ma Qinghua}

sentence-succession.

\subsection{Zero sentence-coordinate conjunctions}

Whether a word-coordinate conjunction can be raised to a sentence-coordinate conjunction or not depends on the degree of the need for sentence-coordinate conjunctions, as demanded by the cohesion of a compound sentence. The need for a sentence-coordinate conjunction in turn depends on the cohesion of the clauses juxtaposed in compound sentences of various languages. For example, the loosest type of coordinate clauses in modern Chinese lacks an explicit conjunction (e.g. (13)), whereas in English, sentence cohesion is achieved by the use of "and" in similar cases (Lü Shuxiang 1980).

(13) Cūn wài duīzhe dàgāo de liángshi, yì zú rén xiàng zài nàli yángcháng ne. (村外堆着大高的粮

食, 一族人像在那里扬场呢。/ Grain was piled high and large outside the village, <and> a group of people seemed busy with winnowing.)

Although both conjunctions and zero conjunctions can be used, conjunctions are used far more frequently for word coordination than for sentence coordination. It is so because word coordination reflects a low-level structural relation in syntax, as the basis on which the high-level structures are formed, and the higher-level structural units need its constituents to be marked clearly. Sentence coordination, on the other hand, is not conditioned as word coordination is, since the former is on a level nearer actual communication, relatively independent of structure. Hence, on that level, the use of a lexical item to mark the sentence-coordinate relation might become superfluous. For example in Primi, Aching, Hani, Lhoba (Bengni-Bokr), between "word-coordinate phrases is often put a conjunction," and "between two clauses of a compound sentence, a conjunction is generally not used." In Zuona Monba, for word coordination a conjunction is optional, but between coordinate clauses in a compound sentence, a conjunction is generally not used. Whether the word-coordination function of a conjunction could, in the course of semantic change, be upgraded to that of sentence-coordination, is constrained by its competition with other means of sentence-coordination (e.g. the relative adverbs, which indicates coordination, etc.). For example, Miao language (Miao-Yao group, Sino-Tibetan family) has $t c a \eta^{33}$ (a word-coordinate conjunction), no $^{31}$ (a sentence-transition conjunction), and the adverb which indicates sentence coordination, but Miao has no sentence coordinators.

Since so few explicit forms mark sentence coordination, and since word transition and word succession have not much need for marking, the conjunctions that remain are often polysemous between word coordination, sentence transition, and sentence succession. Take "word coordination $\diamond$ sentence transition" for example first. Mawo Qiang (a language in the Sino-Burman group) has the word-coordinate conjunction $n i$, and the sentence-transition conjunction $1 a$, but no clause-coordinate conjunctions; and Derung language has word-coordinate conjunction $\mathrm{nin}^{55}$ and clause-transition conjunction 


\section{The Path of Grammaticalization for Coordinate Conjunctions and its Universality}

$p u u^{31}{ }^{1}{ }^{2} i^{55} 、 b a \check{i} i^{54} 6 u i^{31}$ but no clause-coordinate conjunctions ${ }^{5}$. Li (Zhuang-Dong group, Sino-Tibetan family) uses Pom $^{3}$ as both word-coordinate conjunction and clause-transition conjunction. The coordinate conjunction bitftfi of Ewenki (Manchu-Tungusic group, Altai family) is often used between two adjectives and used in a compound sentence to express transition, and "the latter case is relatively more frequent." The word-coordinate conjunction şi in Romanian (Latin group, Indo-European family) has the basic meaning "and", with the function of clause transition in folk speech. There is likewise the polysemy of "word coordination $\diamond$ sentence succession". For example, $n^{1} h_{t o m} 、 n^{1} a^{2}$ in Jingpo (Enkun) (belonging to the Tibeto-Burman group, Sino-Tibetan family), are word coordinators linking two adjectival elements and word-succession conjunctions linking two verbal elements (thus distinguishing their sequence), and both at the same time middle-position words standing between two parallel items; if used as clause-succession words, they shift to stand at the end of the former-item clause. It is seen from the above observations that in the conjunctions' polysemy "word coordination $\diamond$ sentence transition", "word coordination $\diamond$ sentence succession" or "word coordination $\diamond$ sentence transition $\diamond$ sentence succession", the change takes place in a certain order: "coordination>succession: transition."

\subsection{The changes of adjunction and linkage}

A case-marking element $(\mathrm{CM})$, such as a preposition or a case auxiliary, can change into a conjunction, and a conjunction can change into an adjunct to the predicate verb. Examples of this kind of internally-motivated change have provided, from various angles, the evidence that conjunctions travel the path "juxtaposition>succession: transition".

\subsubsection{The change from a $\mathrm{CM}$ to a conjunction}

Due to their semantic similarity, the coordinate conjunctions have a natural and universal relation with the CMs signifying togetherness. In Chinese, for example, “与(yǔ)”, “同 (tóng)”, “跟 (gēn)”and“和(hé)” are all simultaneously coordinate conjunctions and prepositions or case markers for togetherness. It is a focus of discussion as to which of them came into being first, which of them later. This problem can be answered against the broad background of the etymological relation between the conjunction and the CM.

Early on, most scholars agreed that first a verb developed into a $\mathrm{CM}$, a process of incomplete grammaticalization, and then into a conjunction, a process of full grammaticalization. Jiang Jicheng (1997), a proponent of this view, said, for instance, that conjunctions “共(gòng), 将(jiāng), 和(hé) and 同(tóng), etc.” in early modern Chinese had resulted from the prepositions expressing the meaning of "togetherness". Chen Yongzheng (1986) stated, "The conjunctions in the earlier time were changed into prepositions from

\footnotetext{
(5) Derung, nevertheless, has clause-coordinate adverbs.
} 


\section{Ma Qinghua}

verbs through grammaticalization, and then further from prepositions into conjunctions." Chen noted cautiously in his paper that at the onset of the development of a verb into a preposition, the function was almost something between a conjunction and a preposition, whose usage was hard to distinguish from that of a conjunction.

Similarly, in the polysemy between the conjunction and the case auxiliary, the case auxiliary came into being first, and the conjunction later, because the former was the result of the direct grammaticalization of a notional word. Matsumura Akira (1971) said that "the etymology shows that: $t o(と)$, a linking word in Japanese (i.e. our so-called conjunction), is generally considered to have come from the case auxiliary to(と)". Tohti-Litip (2001) pointed out that "Uygur bilän (a coordinate conjunction) came from a postposition (i.e. case auxiliary in our terminology). Historical documents also indicate that the usage of a conjunction could have come into being at a later stage. According to A Dictionary of the Turkic Languages, which was completed in the eleventh century, birlä, a postposition in ancient Turkic, was both a marker of instrument case and that of togetherness case, but was not used as a conjunction at that time (Zhao Mingming 2001).

A contrasting opinion is that the conjunctions came into being first, and then developed into the CMs such as prepositions. This view is novel, but the evidence for it is somewhat scanty. For example, Liu Jian et al. (1992) said that “和(he)," which was a verb in the Tang Dynasty, developed into a conjunction at the same time, and into a preposition in the Song Dynasty ${ }^{\odot}$. However, Dong Zhiqiao \& Cai Jinghao (1994), through inter-textual analysis, offered a counter-opinion, that the use of the word “和 (hé, and )" as a conjunction resulted from the preposition with the meaning of "together". Yu Guangzhong et al.(1999), having analyzed most of the same materials in Liu Jian et al.(1992), proved that the path of change was "[verb (to mix) $] \rightarrow$ [preposition (together) $\rightarrow$ [coordinate conjunction]." The change of a case auxiliary into a conjunction underwent not only the process of continuous grammaticalization semantically, but also syntactically, in that it changed from postposition to a middle-position word ${ }^{\circledast}$.

Each of these two processes can be explained by the other. If conjunctions should develop towards case auxiliaries, the origins of conjunctions themselves were the harder to explain. Due to the preponderance of evidence, the first opinion is adopted here, i.e. whenever there is polysemy of "togetherness case marker $\diamond$ coordinate conjunction", the conjunction has developed from the case marker. This opinion follows the general logic of grammaticalization, i.e. from notional words to functional words (or from less functional to

\footnotetext{
See C.J.Fillmore (1980) for similar opinion.

(7) The changing course of position perhaps takes the reoccurrence of the same item as its transitional phase: “ABx $\rightarrow \mathrm{AxBx} \rightarrow \mathrm{AxB}$ ”, e.g. Japanese “A は B と $\rightarrow \mathrm{A}$ と $\mathrm{B}$ と $\rightarrow \mathrm{A}$ と B”.
} 


\section{The Path of Grammaticalization for Coordinate Conjunctions and its Universality}

fully functional). The changes from prepositions and case auxiliaries to conjunctions, then, go from CMs to conjunctions or from adjunction to linkage.

Furthermore, based on the direct etymological relation between coordinate conjunctions and togetherness $\mathrm{CM}$, it is inferred that whenever the polysemy consists of "togetherness $\mathrm{CM} \diamond$ coordinate conjunction $\diamond$ transition conjunction $\diamond$ succession conjunction", a conjunction's usage for transition and succession generally develops internally out of usage for coordinate linkage. See $\S 2$. Semantic Analysis for more details on the relation between $\mathrm{CMs}$ and coordinate conjunctions.

\subsubsection{The expansion of a linker to an adjunct of the predicate verb}

The coordinate conjunction linking predicate verbs can change gradually into adjuncts to them. They can indicate, to a certain degree, a time relation analogous to the succession relation. Some examples are provided by two languages in the Tibeto-Burman group of the Sino-Tibetan family. In the Yi language, the word-coordinate conjunction $s r^{33} n r^{21}$ linked two substantivals, and when linking a verb and a subject-predicate phrase or a verb, becomes a resultant-complement marker expressing sequence. Chen Kang et al. (1998), through literal translation of (14) and idiomatic translation of (15), showed how it changed from indicating juxtaposition to indicating succession:

(14) $\operatorname{tshi}^{33} \mathrm{ndzi}^{33} \mathrm{ndo}^{34} \mathrm{ndo}^{33}<\mathrm{sI}^{33} \mathrm{nI}^{21}>\mathrm{ZI}^{55} \mathrm{o}^{34}$ (He wine drank drank and drunken [literal translation], i.e. He was drunken. )

(15) $\mathrm{nol}^{34} \mathrm{nol}^{33}<\mathrm{SI}^{33} \mathrm{nI}^{21}>\mathrm{phi}^{21} \mathrm{ndI}^{21} \mathrm{na}^{33}$ (sat sat and hip pained [literal translation], i.e. sat to the point of hip-paining)

Chen Shilin et al. said (1985), "the use of $s r^{33} n r^{21}$ as a resultant complement marker is an extension of that of $s I^{33} n r^{21}$ as a conjunction."

A second example comes from Jingpo (Daiva). $e^{255}$ is a word-coordinate conjunction that links substantive or predicative phrases. When it links two successive acts, it indicates succession, not simultaneous coordination. Xu Xijian et al. (1984), using example (16) below, made it clear that the internal sense-change of the Jingpo conjunction $e^{255}$ "coordination>succession" followed in fact the logic for sense-change similar to that of $s I^{33} n r^{21}$ in Yi language.

(16) $\mathrm{jan}^{31} \mathrm{ju}^{51}<\mathrm{e}^{255}>\mathrm{phan}^{51} \mathrm{pe}^{51}$ (literally, He took ran away, i.e. He took it and ran away) ${ }^{\circledR}$

\section{Semantic Analysis}

\subsection{The origin of the coordinate sense items}

The coordinate sense-items often result from the direct change of the non-coordinate words meaning togetherness, togetherness, sameness, and nearness (collectively-called $\mathrm{x}$ ).

\footnotetext{
(8) Here, the usage of the conjunction $e^{255}$ in Yi language is the same with that of English "and" but different from Chinese usage.
} 


\section{Ma Qinghua}

The path of this external change is more or less universal. The following are some examples for each type.

\subsubsection{Words meaning togetherness}

Togetherness CMs/verbs with their accompanying meanings were the most general source of coordinate conjunctions. Instrumental mark/agency verb are also universally turned into coordinate conjunction. It is in fact the metaphor of togetherness or accompanying sense, because instruments are used together with agents.

[Togetherness $\mathrm{CM} / \mathrm{verb}$ of accompanying sense $>$ coordinate conjunction] “与(yǔ)、暨 $(\mathrm{j}$ i) ${ }^{\oplus}$ " in Archaic Chinese, the togetherness case preposition $P u: I \eta^{2} 、 k h u^{l}$ in Li language, the togetherness preposition mai in Wa language, the togetherness case auxiliary $\operatorname{ta}^{6} \eta^{13}$ in Tibetan language, are all word-coordinate conjunctions concurrently. The verb “比(bǐ)” in the oracle inscriptions, which indicated togetherness, was also used as a coordinate conjunction. The meaning of “并(bìng)", whose archaic form was like two men standing together, was extended from its original meaning to a coordinate conjunction (without progression sense) (Zhao Cheng, 1988).

[The instrumental $\mathrm{CM} / \mathrm{verb}$ with the performative sense>coordinate conjunction] the $e^{231}$ in Jingpo(Enkun) is an instrumental case auxiliary, but is used also as word- and clause-coordinate conjunction $\left.{ }^{(}\right)$; menen in Kirgiz, an instrumental case auxiliary, is used also as word-coordinate conjunction (Hu Zhenhua 1986); bilen in Tuva, an instrumental case auxiliary, and togetherness case auxiliary, is also used as a coordinate conjunction; bilän in Uygur, an instrumental case auxiliary, is also used as a coordinate conjunction. “将”(jiāng) in Chinese was used as an instrumental CM in the Pre-chin period (see (17)), as in Yang Jing's note on Xun Zi: “将, it means 'with'." And its use as a coordinate conjunction came late, as in (18) (Yang Bojun et al. 1992). Zhao Cheng's opinion (1986) that "以(yî)" which was used as a coordinate conjunction in the oracles seems a sound-loan word should be considered incorrect, since it ignores the etymological relation between the instrumental $\mathrm{CM}$ and the coordinate conjunction.

(17) Sū Qín <jiāng> liánhéng shuì Qín Huìwáng. (苏秦始〈将>连横说秦惠王。(《战国策》) / Su Chin tried at first to persuade King Chin Hui <with> the policy of "horizontal alliance." (Strategies of the Warring States Period))

(18) Tăng yù luán <jiāng> hè, shuí lùn diāo yǔ chán. (倘遇变<将>鹤, 谁论貂与蝉。(卢照邻诗)/ If meeting with luan <and> he, could one talk about Diao and Chan ${ }^{(1)}$ ? (a poem by Lu Zhaoling))

\footnotetext{
(9) It also indicated “到（dào)、及(jí)” (meaning “to; to get, to reach,” e.g. “上求不暨, 是为外利也（国 语)" “The king did no get what he asked for, it was called interest outside of his own" ( 《States'Annals》). (10) The sound transcription by Liu Lu (1984) is adopted here, but Dai Qingxia et al. (1992) transcribed it as "the ${ }^{(1)}$ ".

(11) "He" means a crane, and "luan" is a kind of bird similar to a crane in imagcry, and both stand for male
} 


\section{The Path of Grammaticalization for Coordinate Conjunctions and its Universality}

\subsubsection{Words with the sense of sameness}

Words expressing sameness sometimes are changed into those expressing coordinative linking. This kind of change is weakly universal.

[Words with the sense of sameness $>$ coordinate conjunction] “同(tóng)" denoting sameness in Early Modern and Modern Chinese changed to become a preposition indicating sameness at first, and then a coordinate conjunction (Jiang Jicheng, 1997). “为”(wéi) in the oracle and bronze inscriptions indicated "to do, to be", and in Archaic Chinese was changed into a coordinate conjunction (see below). Two copulas, log and $l o$ in Lhoba language also are concurrently coordinate conjunctions.

\subsubsection{Words with the sense of nearness}

These words which could change into coordinate conjunctions share, in the main, two types of meaning: likeness (类同) indicating the nearness in features, and proximity (比及) indicating the nearness (either in space or time).

[Words with the senses of likeness $>$ coordinate conjunctions] “若(ruò)" in Archaic Chinese indicated “如同、像” (meaning "like” (e.g. (19)) and changed into a coordinate conjunction, which linked substantivals (e.g. (20) and predicates (e.g. (21)).

(19) Jīfū <ruò> bīngxuě, nàoyuē <ruò> chǔžr. (肌肤<若>冰雪, 淖约<若>处子。(《庄子》)/ (Her) complexion white <like> snow, elegance and gentleness <like> a maiden. (Zhuang Zi))

(20) Xī jǔ mínshì cáimù, wă <ruò> lìnshí shù, shǔ cháng duăn dà xiăo. (悉举民室材木、瓦<若>萄石

数, 署长短大小。(《墨子》)/ (They) all took some wood, tiles <and> stone in civil use to see which was longer and larger.(Mo-tse))

(21) Shí yǒu jūnyì <ruò> zāo shuǐ hàn. (时有军役<若〉遭水旱。(《汉书》)/ (They) served in the army often, like suffered from flood and drought. (Han Shu))

"And", a coordinate conjunction in English, had an old and now obsolete usage of "as if, as though"(The Oxford English Dictionary, Clarendon Press, Oxford, 1989). This usage was grammaticalized further to a suffix indicating the sense of likeness, /-an/, e.g. Mozartean.

[Words with the sense of proximity>coordinate conjunction] Shuowen Jiezi: 及(jí) means to reach. In the inscriptions on oracles and bronze, its meaning was indicated by a hand having reached a man. It is also used as a coordinate conjunction (以及[yíí]).

Near (proximal) deictic (“这”(zhè)、“这样” (zhèyang), and near ( $2^{\text {nd }}$ person) reference (“你”nǐ) in Chinese are the result of grammaticalized substantivals with the sense of approaching, and their realization in pronouns. Quite a few coordinate conjunctions in various languages also have senses of near deictic and near reference; their close

birds, whereas "diao" and "chan" implies female. So, the line of poem reads roughly as "If met with men, could one talk it as women?" 


\section{Ma Qinghua}

relationship provides further evidence proving the change of "words with approaching senses > coordinate conjunctions", and near deictic had also a important effect on the appearance of the successive senses (see below).

These various senses - reaching, likeness, instrument, togetherness - are psychologically related, giving rise to polysemous, synonymous, or cognate relations among words with those denotations. A word with "instrument-togetherness" senses, e.g. birlä in Old Turkic was both an instrumental $\mathrm{CM}$ and togetherness CM. Similarly, a word with "instrument-togetherness-reaching" senses, e.g. 将 (ji āng) in Chinese is used as an instrumental CM, and has the sense of carrying things and that of reaching, as described in Guangya: Words Explanation. Another example of "likeness $\diamond$ reaching," from Chinese, is the word “如(rú),” literally denoting likeness, but in some contexts, such as“不“如”你 (bùrú nǐ, "not like you"), it means "not reaching your level." A word with the sense of "togetherness $\diamond$ likeness", e.g. Сова- in Kangjia (a language belonging to Mongolian group) originally meant "to follow", then changed to mean "being like". Likewise, “像...... 样” ( xiàng......ȳyàng, A's image $B$ the same ......) is equivalent to “跟...... 样”(gēn......yīyàng, “A following B the same”); both mean “A is like B.” “似 (sì)” in Chinese, which indicates likeness, is cognate with “以”(y̌l, and), and was an instrumental CM. “是(shì)” in Chinese, which expressed the sense of near deictic in the Ancient Time but is a copula in Modern Time, could indicate metaphor. The meaning expressed by various sense-items of $x$ can all be summed up as "identification". In general, only the elements with the same or near senses can form coordinated constructions. It seems that the motivation for the use of $\mathrm{x}$ expressing "identification" as coordinate conjunctions is based on the recognition of the essence of coordinate relations.

Analyses show that a coordinate conjunction was derived from more substantival (not fully grammaticalized) forms in $\mathrm{x}$. It is inferred that when "words with $\mathrm{x} \diamond$ coordinate conjunctions $\diamond$ transitional conjunctions $\diamond$ successive conjunctions" constitute a polysemic relation, the transition or succession use of a conjunction is generally derived from the coordinate use through internal changes. Below are several examples from Archaic Chinese.

[用 (yòng) ] Its original image was a handled-bucket and its extended meaning is "to use" (Yu Xingwu, 1978). During the Western Zhou Dynasty, it was grammaticalized into a preposition, and came to be used as a conjunction (Chen Yongzheng,1996). According to Guan Xiechu (1987), in the inscriptions on bronze, there was one example of the use of “用” to link substantivals indicating coordination, one example to link adjectival predicates indicating coordination, and 160 examples to link clauses indicating succession. Here, in cases where there is polysemy between "instrumental $\mathrm{CM}$ /words of the performative sense $\diamond$ coordinate conjunction $\diamond$ successive conjunction", the successive meaning of a 


\section{The Path of Grammaticalization for Coordinate Conjunctions and its Universality}

conjunction appears to have arisen from the coordinate conjunction through internal change. Although the successive use was overwhelmingly greater than other uses in frequency, this did not prove that it enjoyed priority over others in etymology. There is no correspondence between high frequency and original meaning, hence the purpose of differentiation of the original meaning from the basic meaning.

[以 (yǐ)] "以” in the inscriptions on oracles was pictured as a plough, a kind of farm tool. Shuowen Jiezi notes: “以” means to use. During that period, it was used as an instrumental CM (preposition). “以”indicates near deictic (e.g. (22)) and is used as a coordinate conjunction (e.g.(23)) (Zhao Cheng 1986). According to Guan Xiechu (1981) there were later 4 examples in the inscriptions on the bronze of the Western Zhou in which "以" linked substantivals indicating juxtaposition (word-coordination), and 4 examples in which it linked clauses indicating succession (clause-succession). We see that the latter then developed into the usage of the transition conjunction (e.g.(24)). Here, when the polysemy is among "instrumental CM or verb with the sense of performance / word with the sense of approaching $\diamond$ coordinate conjunction $\diamond$ succession conjunction $\diamond$ transition conjunction", the above evidence shows that the coordinate sense of a conjunction came first, and the succession sense and transition sense came into being on the basis of that.

$(22)<Y r$ > yán wèi xìn zé băi shì bù măn ye. (<以>言未信则百事不满也。(《吕氏春秋》) / All things, with their explanations unbelievable, do not go well. (Lü’s Spring and Autumn Annals))

(23) Xīnyǒu zhēn, wáng lìng Wú <yì> Zǐfāng diàn yú Bīng. (辛西贞, 王令吴<以>子方奠于并。/ The king, by divination in the year xin you, ordered $\mathrm{Wu}<$ and> Zifang to make offerings to the spirits of the dead at Bing (place).)

(24) Yáo wú băi hù zhī guō, Shùn wú zhì zhū zhī dì, <yǐ> yǒu tiănxià. (尧无百户之郭, 舜无置雉之 地, <以>有天下。(《淮南子》)) / Yao did not have any city of one hundred households and Sun not an inch of land either, <nevertheless>, they ruled the whole country. (Huainan Zi)

[为(wéi)] In the inscriptions on oracles and bronze, “为” meant “to do, to be" and was changed to be a coordinate conjunction in Archaic Chinese (e.g. (25)), and a succession conjunction (e.g. (26)). When the polysemy consisted of "verb with the sense of equivalence $\diamond$ coordinate conjunction $\diamond$ succession conjunction", the succession usage of a conjunction came into being after its coordinate use.

(25) Mín zhī wèi lì, zhí dào <wéi〉 kòu. (民之未庆, 职盗〈为〉寇。(《诗经》) / People, when not enjoying a peaceful life, turned to be thieves and bandits. (The Book of Songs))

(26) Jīng <wéi> yì rŭ. (精<为>易辱)。(《国语》) / Over-elegant people are apt to be disgraced. (Discourse on the States))

[若(ruò)] In ancient Chinese, it meant "the same"(see above), and "to reach"(e.g.(27) below). It served as the proximal deictic (this, so) (e.g..(28)), and as the "near" reference (you) (e.g. (29)), and it was a conjunction (see above), including the sense of succession 


\section{Ma Qinghua}

(e.g.(30) and (31)). In cases where the polysemy consists of "Words with the sense of the sameness / words with the sense of approaching $\diamond$ coordinate conjunction $\diamond$ succession conjunction", the succession usage of a conjunction resulted from the coordinate usage through internal change.

(27) Bìng wèi <ruò> sǐ. (病未<若〉死。(《国语》)/ So sick <near > death. (Discourse on the States))

(28) Y̌̃ <ruò> suǒ wéi, qiú < ruò> suǒ yù. (以<若〉所为, 求〈若〉所欲。(《孟子》)/ by 〈so> doing in order to get what one wants (Mencius))

(29) <Ruò> guǒ yăng hu? (<若>果养乎? (《庄子》)/ Did <you> really nurse your health? (Zhuang

$\mathrm{Zi})$ )

(30) Jūnž guàiguài dú xíng, yù yǔ <ruò> rǔ. (君子夫夫独行, 遇雨<若>濡。(《易》) / A gentleman walked lonely <and> he got wet in the rain. (The book of changes))

(31) Bì yǒu rěn ye, <ruò> néng yǒu jì ye. (必有忍也, <若>能有济也。(《国语》)/ You had to be tolerable <and> could be well. (Discourse on the States))

[且(qiě)] According to A collection of Notes on the Function Words in Ancient Books by Pei Xuehai: "且 meant approaching." The notes by Hu Sansheng on Zi Zhi Tong Jian(Shima Guang's Chronicles) read:“且, a word expressing nearly reaching”. “且” indicated near deictic"(e.g. (32)); it also linked adjectives or verbs indicating juxtaposition (e.g. (33)), and it linked clauses indicating succession (e.g.(34)), and it also expressed a transition (e.g.(35)). However, Yan Bojun and He Leshi (1992) believe that its usage of transition "was very rare". When the polysemy consists of "words with the sense of approaching $\diamond$ coordinate conjunction $\diamond$ succession conjunction $\diamond$ transition conjunction", the successive, transitional usage of a conjunction came from the coordinate usage through internal changes.

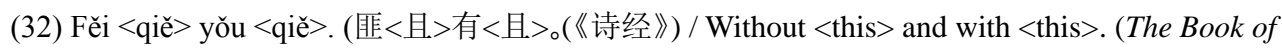
Songs))

(33) Jūnž̃ yǒu jiǔ, zhǐ <qiě> duō. (君子有酒, 旨<且>多。(《诗经》) / Gentlemen have fragrant <and> fine wine. (The book of Songs))

(34) Xiān jué Qí hòu zé dì, < qiè> bì shòu qī yú Zhāng Yí. (先绝齐后责地,<且>必受欺于张仪。(《战 国策》) / (You) would break off relations with the state of Qi first, and then demand land from it, <and> by that you would certainly be deceived by Zhang Yi. (Strategies of the Warring States Period))

(35) Qiū néng rén < qiě $>$ rěn, biàn < qiě $>$ nà, yǒng $<$ qiě $>$ qiè. (丘能仁 $<$ 且 $>$ 忍, 辩 <且 $>$ 讷, 勇 $<$ 且 $>$ 怯。(《论衡》) / Qiu could be benevolent <but> tolerate, eloquent <but> slow in utterance, and brave<but> physically weak.(On Balance))

[而 (ér) ]“而”denoted similarity (as if, like) (e.g.(36)). In ancient time, “而” and“和” were often exchangeable; as Shi Wen (释文, Explanative Notes on the Text in ancient time) stated: in one text the words “如...... 如......” in (37) were both replaced by “而”. The 


\section{The Path of Grammaticalization for Coordinate Conjunctions and its Universality}

word also expressed near reference (you: both singular and plural) (e.g. (38)); “而” as a conjunction was not seen in inscriptions on oracles and the bronze during the Western Zhou Dynasty, and there were only two examples with clear indications in the literature of the Spring and Autumn Times (Chen Yongzheng, 1986), one of which denoted juxtaposition, another sub-succession. After that period, such examples of “而” used as a conjunction began to appear frequently (Cui Yongdong, 1984), and an example of its word-transition function was found in (39). Thus, when the polysemy consists of "words with the sense of the sameness/words with the sense of approaching $\diamond$ coordinate conjunction $\diamond$ succession conjunction $\diamond$ transition conjunction", the successive, transitional usage of a word came from its coordinate usage through internal change. The source for the usage of 而 as a coordinate conjunction, which many people consider to be unknown, is in fact clear.

(36) Bǐ dū rén shì, chuí dài ér lì. Bǐ jūn zǐnŭ, juăn fà <rú> chài. (彼都人士, 垂带而厉。彼君子女, 卷 发〈如〉蒀。(《诗经》)/ The ribbons the gentlemen of that town wore were hanging down <like> tassels, and their sons' and daughters' hair curly <like> waves.(The Book of songs))

(37) Wáng fèn jué wǔ, $<$ rú > zhèn $<$ rú> nù. (王奋厥武, <如>震〈如〉怒。(《诗经》) / The king felt very angry, his blood <like> boiling-water.(The Book of Songs))

(38) Yù <ér> zhèng yú Zāng zhàng rén, shùjī hu mín yǒu liáo hu. (寓<而>政于臓丈人, 庶几乎民有 療乎。(《庄子》)/ To entrust <your> administrative affairs to this respectful elder with virtue in Zang, then the people's pain could be relieved.(Zhuangzi))

(39) Zĩ wēn <ér> lì, wēi <ér> bù měng. (子温<而>厉, 威<而>不猛。(《论语》)/ You were gentle $<$ but> severe and dignified <but> dear. (The Analects of Confucius))

Remember the case of "and", an English coordinate conjunction with the polysemy of "a word with the sense of the sameness $\diamond$ coordinate conjunction $\diamond$ succession conjunction $\diamond$ transition conjunction", and the case of Japanese $t o(と)$, with the polysemy of "a word with the sense of the sameness ${ }^{\circledR} /$ with the sense of likeness/togetherness $\mathrm{CM} \diamond$ coordinate conjunction $\diamond$ succession conjunction". From these two as well as the examples in the paragraphs above, it is inferred that their coordinate usage came first, and the succession and transition usage later.

\subsection{The origin of transition senses}

Some grammar books group all the transition sentences as subordinate sentences (for example, $\mathrm{Hu}$ Yushu, 1984:404) and some mainly as compound sentences (for example, $\mathrm{Li}$ Jinxi (1933)). Actually, there are two types of transition sentences, i.e. "parallel transition" and "subordinate transition (e.g. concession) sentences, which belong respectively to the compound and subordinate categories. Ma Qinghua (2005), based on the relation of meanin $\mathrm{g}$ changes, distinguished two types of transition, i.e. parallel transition and series transition.

\footnotetext{
${ }^{\mathbb{1}}$ In Mr. Tokieda Masaki’s theory of grammar, $t o($ と $)$ is regarded as a form of $d a(た ゙)$ in successive use.
} 


\section{Ma Qinghua}

Take the former, it can be the same constructions in juxtaposition (e.g (40b) is the same construction as (40a)), those in opposition ${ }^{\circledR}$ (e.g (41b) is the opposite of (41a)) and those compact constructions in contrasting juxtaposition ${ }^{\circledR}$ (e.g. (42b) is the opposite of (42a):

(40)a. Nǐ qǔ, wǒ bú qù. (你去, 我不去。/You go and I don't.) (juxtaposition)

b. Nǐ qŭ, wǒ bú qù.(你去, 我不去。 / You go but I don't.) (transition)

(41)a. Wǒmen y̌̉jīng péiyăngle bùshăo réncái, mănzúle shíjì xūyào. (我们已经培养了不少人才, 满

足了实际需要。/We have trained many talents and met the actual need. )(juxtaposition)

b. Wǒmen yỉjīng péiyăngle bùshăo réncái, $<$ dàn> hái bù néng mănzú shíjì xūyào. (我们已经培 养了不少人才, <但>还不能满足实际需要。/ We have trained many talents < but > cannot meet the actual need.)(transition)

(42)a. Dàjiā dōu láile, tā chídàole. (大家都来了, 他迟到了。/ All of us came and he was late.)(contrast)

b. Dàjiā dōu láile, tā<què> chídàole. (大家都来了, 他<却>迟到了。/ All of us came <but> he was late.)(transition)

The same constructions were changed by shifting. The compact constructions were achieved by the addition of relevant elements or assisted by their affirmative or negative transformation. It is characterized by controlled shift. The opposition relation was changed by either shifting or controlled shift. We therefore conclude that the transition relation appeared later than the coordination.

The transformation of the same constructions takes place between the typical and atypical coordinate relations. Before a new connective function was lexicalized, it often appeared first in the capacity of an atypical usage. Almost all coordinate constructions in modern Chinese (for example, “既 A 也 B”, “既 A 又 B”(both A and B), “一面 A 一面 B”, “又 A 又 B"(A on the one hand and B on the other), etc.) can imply the sense of transition (Xing Fuyi, 1998). Compare (43) with (44):

(43) Wǒ $<\mathrm{ji}>$ bù xiăng zànměi zhè zhǒng yīnyuán, $<$ yě $>$ bú yuàn zài cǐkè yòng yáncípòhuài tāde xīnjìng. (我<既>不想赞美这种姻缘, 〈也>不愿在此刻用言辞破坏她的心境。／I will<neither> speak highly of this conjugal felicity, nor disturb her mood by speech.) (typical juxtaposition )

\footnotetext{
(2) The full name of “the opposite(对式)" is“the opposition construction (对立式)”. The term was coined with reference to the contradictories in N.Smith \& D. Wilson (1979).

${ }^{(1)}$ It can also be a progressive-compatible construction and the compatible construction is another means of addition. Compare:“他听着, 这姑娘的形容很奇怪, 更奇怪的是她形容得挺准确（He is listening, thinking this girl's description very strange, and furthermore, very accurate (progression)) 他听着, 这 姑娘的形容很奇怪, (但) 更奇怪的是她形容得挺准确（张承志《北方的河》(He is listening, thinking the girl's description very strange, (but)what's more, very accurate (Zhang Chengzi《The Northern River $\rangle$ ) (parallel transition) ) ". This shows that in transformation, the transition relation came later that than other joint relation.
} 


\section{The Path of Grammaticalization for Coordinate Conjunctions and its Universality}

(44) Tā <jì> kěyǐ shuō hàokè, <yě> kěyǐ shuō bú hàokè. (他<既>可以说好客, <也>可以说不好客。/ He could be said to be <both> hospitable <and> inhospitable. (atypical juxtaposition, with the implicature of transition)

Coordination is typical of compound sentences and its characteristics are weak. Once the former or the latter item means implicit transition, that sense easily shows from behind the coordination. Hence, the insertion of “但 (dàn) ", a transition word, at the beginning of the second clause in (44) does not change the meaning. Only when the veil effect of coordination wore out in the atypical coordinate usage implying transition, could the new sense-item expressing transitional function be established. Besides, in the atypically coordination implying transition, only a pure coordinate conjunction can have compatibility with transition conjunction (compare (45a) with (45b)), but not vice versa (compare (46a) with (46b)). This is the basis for the sequence "coordinate>transition" instead of the reverse process. The lexicalization of this sequence of structure resulted in this path of grammaticalization.

(45) a. Zhè háizi hěn cōngming, <yě> hěn qiānxū. (这孩子很聪明,<也>很谦虚。/ The boy was clever<and> modest.)

b. Zhè háizi hěn cōngming, < dàn > <yě> hěn qiānxū. (这孩子很聪明, <但 $><$ 也很谦虚。/ The boy was clever $<$ but $><$ and $>$ modest.)

(46) a. Zhè háizi hěn cōngming, $<$ dàn $>$ bú yònggōng. (这孩子很聪明, <但 >不用功 。/ The boy was clever $<$ but $>$ did not work hard.)

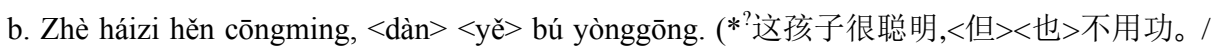

*? The boy was clever $<$ but $><$ and $>$ did not work hard.)

Although semantic contradiction between the former item and the latter item is the origin giving rise to transition function derived from coordinate conjunctions, transitional function motivated directly from outside of the relevant domains can hardly cause in return the production of the coordinate function by semantic means. The transition conjunctions, for example, “但（但是）(but), 只是, 不过 (however, nevertheless)” in Chinese, “but" in English, "damu" in Manchu, etc., which transformed from a few category words ( originating by the principle of euphemism), do not have the coordination usage.

\subsection{The origin of succession senses}

Succession can be regarded as a specialized coordination. A coordinate conjunction can link constructions of various kinds, but a succession conjunction generally links verbals or clauses, because only the latter admits of time sequence. When there is a temporal sequence between two actions or events in juxtaposition, the original coordination can naturally reveal a sense of succession. The similarity between the coordination and the succession seems to be greater than that between the coordination and transition. No wonder some linguists have included succession within the coordination. The lexicalization 


\section{Ma Qinghua}

of the sequences of structural changes "coordination > succession" gave rise to the grammaticalization "coordination>succession" in conjunctions.

In Spanish, clause coordinator " $y$ " connects two affirmative clauses in juxtaposition. If the tense of the first clause comes before that of the second one, then succession sense was expressed. The change seems to have been realized by taking the parallel coordinate structure as a constant, and the time sequence as a variable. Then, in cases where one clause is in the affirmative, but the other is negative, a transition comes into being.

A coordinate conjunction, e.g. the coordinate conjunction “并且(bìngqiě, and)" in Chinese, can be used in expressing succession. See (47).

(47) Tā bă kēng tiánmăn, < bìngqiě> yònglì zài shàngmian căi le jǐ jiăo. (他把坑填满, <并且>用力在

上面踩了几脚。/ He filled the pit(with earth), <and> stamped it hard several times.)

Although the successive sense of “并且”"is not found in dictionaries, it can be said at most that the relation has not been lexicalized yet. The succession conjunction (e.g. 然后 ránhò $\mathrm{u}$, then) motivated directly from outside of the relevant domains can hardly be used as a coordination marker. This is further evidence for the grammaticalization path "coordination>succession" in conjunctions.

The fact that the coordinate sense of a conjunction changed internally to successive sense and transitional sense does not mean the coordination is a stimulant to produce successive sense and transitional sense; rather, it only provides the structural condition for it. Only the concrete relation of senses between the former-item and latter-item, for example, the time sequence or affirmative-negative relation, is the fundamental stimulant. As stated above, a near deictic, as a realization of approaching sense in pronouns, appears in the polysemic system of the coordinate conjunctions. The combination of the near-deictic sense-item (这 [this]) with the structural conditions and the sense-relation between the former-item and the latter-item, could quicken the lexicalization of a succession conjunction. Succession involves the sequence in time, whereas a proximal deictic in itself does not involve sequence. It can, however, express a confirmation of a fact in anaphoric usage, and become a natural marker for time sequence. так in Ukrainian, used as an adverb, means "this way, so"; as a conjunctions, it means “then, so." So is “是(shì)” in Archaic Chinese, cf. (48). Lü Shuxiang (1985) stated, “这(zhè, this)" means "then" and "like this", with succession function, as seen mainly in idioms “这就(zhè jiù)、这才(zhè cái)、这可(zhè kě)”(e.g.(49)) $)^{\text {(2) }}$.

\footnotetext{
(12) A near deitic could also express causes which were the former-latter relations in things and reasons. For example, “此(cî)”, a near deitic pronoun, indicated the results: “有德此有人, 有人此有土, 有土此有财, 有财此有用 (《礼记·大学》)”(The fact that one is resulted in the fact he has men, then the land, and money, and useful facilities( 《The Book of Rites.Great Learning》)). "So" in English is used as an adverb of degree, indicating "by this way"; as a conjunction, indicating "hence". eva, an adverb in Old Sanskrit, indicating "so", and "like this way, hence" too.
} 


\section{The Path of Grammaticalization for Coordinate Conjunctions and its Universality}

(48) Sāng tǔ jì cán, <shì> jiāng Qiū zhái tǔ. (桑土既蚕,<是>降丘宅土。(《尚书》)/ He)raised silkworms on the mulberry field, <this way> gave Ciu house land. (Book of Documents))

(49) Tā xiěwán le yòu niàn gěi tā tīng, <zhè> cái fēnghăo.(写完了又念给他听, <这>才封好。/

Having finished and read to him, (he) $<$ then $>$ sealed the letter.)

\section{Conclusion}

Analysis shows that "coordination>succession: transition" is a well-worn path in the grammaticalization of coordinate conjunctions, a path showing the development of specific structural relations out of forms that originally denoted non-specific structural relations. The relative universality of this pattern further supports the claim that in most cases the higher the abstraction of sense classes, the more identical the conceptual motivations are (Ma Qinghua, 2000: 96-121). This path represents only the tendency of change, but not a rule without exception, i.e. it does not mean that coordinate conjunctions must develop into successive or transitional conjunctions, nor vice versa, that the latter must develop from the former, for it is possible for markers of succession and transition to have been motivated from outside of the relevant domains, and in addition there are the ways of external change, etc. In general, the simpler, older, and commoner the conjunction is, the more dominant in colloquial use the connective form is, the closer it is related to prototype, and the more possible the grammaticalization. For example, the expansion of one-syllable conjunctions in Archaic Chinese was more active, but in modern Chinese, owing to its more developed connective means, two-syllable conjunctions are in the state of inertia and single meaning. This has confirmed Li Yingzhe (2001)'s point, that the development of conjunctions could often be divided into two phases of activity: appearance in groups and progressive formation, and the large-scale grammaticalization of conjunctions took place mainly in the former phase (for Chinese, it was respectively in the Spring-Autumn and Warring-States period, 770-221 BC and in the Dynasties of Song and Yuan, 960-1368). The lengths, directions, the degrees of the expansion of conjunctions can vary, i.e. some would change to transition or succession and stop, some continued to expand till they developed into subordinators, but these will be discussed elsewhere.

\section{References}

A Burmese-Chinese Dictionary. 1993. [Z] The Commercial Press.

A New English-Chinese Dictionary. 1984. [Z] The Commercial Press.

A New Indonesian-Chinese Dictionary. 1997. [Z] The Commercial Press.

Bo Wenze.1997. A Study of Yanghuang Language. [M] Shanghai: Shanghai Yuan Dong Publishing House.

Chen Kang \& Wu Da. 1998. A Grammar of Yi Language. [M] Beijing: The Central Nationalities University Press.

Chen Shilin, et al. 1985. A Short Description of Yi Language. [M] Beijing: The Nationalities Press.

Chen Yongzheng. 1986. The Connective Words in the Inscriptions on the Bronze in the Period of the Western Zhou and the Period of Spring-Autumn. [J] Studies on the Old Writing System. Vol. 15. Chung Hwa Book Co. 


\section{Ma Qinghua}

Cheng Xiangqing ed. 1982. A study on the Pre-Qin Chinese. [M] Jinan: Shandong Education Press. Chuck. 1995. A Study of Ewenke Language. [M] Beijing: Nationalities Press.

Cui Yongdong. 1994. A Collection of Notes on the Functional Words in the Inscriptions on the Bronze in the Periods of two Zhous. [Z] Beijing: Chung Hwa Book Co.

Dai Qingxia, et al.. 1985. A Short Description of Aching Language.[M] Beijing: The Nationalities Press.

Dai Qingxia. 1992. A Grammer of Jingpo Language. [M] Beijing: The Central Nationalities College Press.

Dai Qingxia. 1995. An Outline of Hani Language. [M] Kunming: Yunnan Nationalities Press.

Dong Zhiqiao \& Cai Jinghao. 1994. Explanations on the Grammar of the Functional Words in Middle Old Chinese. [Z] Changchun: Jilin Education Press.

Fang Shuxin et al (eds.). 1993. A Dictionary of Ancient Chinese Inscriptions on Tortoise Shells or Bronze Objects. [Z] Bashu Press.

Fillmore,C.J. 1968. The Case for Case. [A] In Bach,E. \& Harms, R.T. eds. Universals in Linguistic Theory. [C] New York: Holt, Rinehart \& Winston, Inc.

Geng Shimin. 1989. A Grammar of Modern Kazak Language. [M] Beijing: Central Nationalities College Press.

Guan Xiechu. 1981. A study on the Grammar in the Western Zhou Inscriptions. [M] Beijing: The Commercial Press.

He Ziran \& Ran Yongping. eds. 2001. Pragmatics and Cognition. [C] Beijing: Foreign Language Teaching and Research Press.

Hu Menhao. 1980. Modern Russian Syntax. [M] Shanghai: Shanghai Yiwen Press.

Hu Yushu. ed. 1995. Contemporary Chinese. [M] Shanghai: Shanghai Education Press.

Hu Zengyi (ed.). 1994. A New Manchu-Chinese Language Dictionary. [Z] XinJiang People's Press.

Hu Zhenhua. 1986. A Short Description of Kirgiz Language. [M] Beijing: The Nationalities Press.

Huang Minzhong et al. 1997. Practical Vietnamese Grammar. [M] Beijing : Beijing University Press.

Huang Yuchen. 1987. Serbian-Croatian Grammar. [M] Beijing: Foreign Language Teaching and Research Press.

Jiang Lansheng. 2001. An Exploration of the Origin of Early-Modern Chinese (All the Quotations from Jiang's papers come from this collection). [C] Beijing: The Commercial Press.

Jiang Jicheng. 1997. Essentials of Early-Modern Chinese. [M] Changsha: Hunan Education Press.

Junast. 1981. A Short Description of Tu Language. [M] Beijing: Nationalities Press.

Li Chinxi. 1924. A New Book on Chinese Grammar. [M] Beijing: The Commercial Press.

Li Chinxi, et at.. 1957. New Theories on the System of Chinese Complex Sentences. [J] Zhongguo Yuwen (Chinese Language). No. 8.

Li Yingzhe. 2001. Some Characteristics in the Development of Chinese Conjunctions. [A] In Li Yingzhe: A Collection of Papers on the Diachronical and Synchronical Grammar of Chinese. [C] Beijing: Beijing Language and Culture University Press.

Li Yongsui, et al. 1986. A Short Description of Hani Laguage. [M] Beijing: The Nationalities Press.

Liang Min. 1980. A Short Description of Maonan Language. [M] Beijing: The Nationalities Press.

Liang Min, et al.. 1997. Studies on Lingao Language. [M] Shanghai: Shanghai Yuan Dong Publishing House.

Lin Shuwu. 2002. Present Conditions, Focuses and Trends of Metaphor Study. [J] Journal of Foreign Languages. No.1.

Liu Guangkun. 1998. Studies on Mawo Jiang Language. [M] Chengdu: Sichuan Nationalities Press.

Liu Jian, et al.. 1995. On Some Factors Inducing the Word-Grammaticalization in Chinese. [J] Zhongguo Yuwen (Chinese Language). No. 3.

Liu Jian, et al.. 1992. Studies on the Functional Words in Early-Modern Chinese. [M] Beijing: The Language Press.

Liu Lu, et al.. 1984. A Short Description of Jingpo Languages (Jingpo Language). [M] Beijing: The Nationalities Press.

Lu Shaozun. 1983. A Short Description of Primi Language. [M] Beijing: The Nationalities Press.

Lu, Shaozun. 1986. A Short Description of Zuona Monba. [M] Beijing: The Nationalities Press. 


\section{The Path of Grammaticalization for Coordinate Conjunctions and its Universality}

Lü Shuxiang. 1982. Essentials of Chinese Grammar. [M] Beijing: The Commercial Press.

Lü Shuxiang. 1985. The Deictic in Early-Modern Chinese. [M] Beijing: Xuelin Publishing House.

Ma Qinghua. 2000. Cultural Semantics. [M] Nanchang: Jiangxi Renmin Publishing House.

Ma Qinghua. 2001. A Collection of Papers on the Syntax and Semantics. [M]Changchun: Jilin People's Press.

Ma Qinghua. 2005. Self-organization of Coordinate Structures. [M] Shanghai: Fudan University Press.

Ma Qinghua. 2006. Multi-Valued Studies on Semantics. [M] Beijing: The Language Press.

Matsumura Akira. 1971. A Dictionary of Japanese Grammar. [Z] Tokyo: Minji Book House.

Sechenchogt. 1999. Kangjia Language. [M] Shanghai: Shanghai Yuandong Publishing House.

Shao Jingmin. 2000. Multi-Valued Studies on Chinese Grammar. [M] Beijing: The Commercial Press.

Shen Jiaxuan. 1994. A Survey of the Studies on Grammaticalization. [J] Waiyu Jiaoxue yu Yanjiu(Foreign Language Teaching and Research). No. 4.

Shen Jiaxuan. 1998. The Mechanism for the word-Grammaticalization: Grammar from Changes: An Introduction and Valuation. [J] Dangdai Yuyanxue(Contemporary Linguistics). No. 3.

Shimura Ryoji. 1995. Studies on Middle Chinese Grammars in China. [M] Beijing: Chung Hwa Book Co.

Smith, N. \& D. Wilson. 1979. Modern Linguistics: The Results of Chomsky's Revolution. [M] Harmondsworth: Penguin.

Sun Chaofen. 1994. A Review of Grammaticalizaztion. [J] Guowai Yuyanxue(Linguistics Abroad). No.4.

Sun Hongkai. 1982. A short Description of Derung Language. [M] Beijing: The Nationalities Press.

Sun Hongkai, et al.. 1985. Monba, Lhoba, Deng People's Language. [M] Beijing: Chinese Social Science Press.

Tian Desheng. 1986. A Short Description of Tujia Language. [M] Beijing: The Nationalities Press.

Tohti-Litip. 2001. A Study on the Grammar of Uygur and other Altaian Languages. [M] Beijing: The Nationalities Press.

Wang Danian. 1997. An Introduction to Burmese. [M] Beijing: Peking University Press.

Wang Fushi. 1985. A short Description of Miao Language. [M] Beijing: The Nationalities Press.

Wang Suoying, et al.. 1999. A Grammar of Portuguese. [M] Shanghai: Shanghai Foreign Language Education Press.

Wang Zhijing. 1994. A Grammar of Lhasa Spoken Language, Tibetan. [M] Beijing: The Central nationalities University Press.

Wu Hongwei. 1999. Studies on Tuva Language. [M] Shanghai: Shanghai Yuandong Publishing House.

Wu Qilu. 1992. Guiyang Bouyei Language. [M] Guiyang: Guizhou Nationalities Press.

Xing Fuyi. 1998. The Study of Chinese Grammar. [M] Changchun: Northeast Normal University Press.

Xu Lin \& Zhao Yansun. 1984. A Short Description of Bai Language. [M] Beijing: The Nationalities Press.

Yang Bojun, et al.. 1992. The Grammar of Old Chinese and its Development. [M] Beijing: The Language Press.

Yang Shunxi. 1993. A Grammar of Romanian. [M] Beijing: Foreign Language Teaching and Research Press.

Yu Shingwu. 1979. A Dictionary of Ancient Chinese Inscriptions on Tortoise Shells. [Z] Chung Hwa Book Co.

Yuan Zhongshu. 1994. An outline of Li Grammar. [M] Beijing: The Central nationalities University Press. Zhang Junru. 1980. A short Description of Shui Language. [M] Beijing: The Nationalities Press.

Zhang xiongwu. 1996. A Grammar of Spanish Language. [M] Beijing: The Commercial Press.

Zhao Cheng. 1986. Exploratious on the Functional Words in the Inscriptions on Oracles.[J] Studies on Old Writing System, vol 15. Beijing: Chung Hwa Book Co.

Zhao Cheng. 1988. A Concise Dictionary of Ancient Chinese Inscriptions on Tortoise Shells. [Z] Chung Hwa Book Co.

Zhao Mingming. 2001. Linguistic studies on Turkic Dictionaries. [M] Beijing: The Central nationalities University Press.

Zhou Zhizhi. 1984. A Short Description of Va Language. [M] Beijing: The Nationalities Press. 